\title{
Prawnicze innowacje?
}

Dziesięć lat temu przygotowywaliśmy pierwszy numer „Forum Prawniczego”. W informacji o celach pisma powtarzamy do dziś główne myśli zawarte w otwierającym tamten numer słowie „od redakcji”. Życzymy sobie, aby na naszym „Forum” dyskutowano o tym, co ważne i aktualne. Bliska naszej wizji pisma jest refleksja o prawie oparta na podstawowych wartościach zakorzenionych w prawie rzymskim, dorobku realistycznej filozofii greckiej oraz chrześcijańskiej tradycji. Chcemy publikować prace wyróżniające się innowacyjnością metod. Z tych deklaracji rodzą się pytania: dlaczego tak jasno wskazujemy źródła wartości, które uznajemy za podstawowe? Czy da się pogodzić silne nawiązywanie do tradycji z otwartością na to, co aktualne? Jak rozumieć oryginalność czy innowacyjność w dyskusji prawniczej? Dziesięć lat redagowania czasopisma potwierdziło wagę tych pytań. Próbę odpowiedzi zacznę od kwestii skrajnych. Podejmowanie tematów aktualnych nie oznacza dla nas zgody na bezpośrednie włączanie się w spór polityczny, ani na ograniczenie do prawa, które tworzy się i stosuje tu i teraz. Deklaracja wartości nigdy nie spowodowała odrzucenia tekstu tylko dlatego, że autor kontestował sens czerpania z europejskiej tradycji prawnej. Te granice pokazują, że wolności dyskusji naukowej o prawie towarzyszy pytanie, jak z tej wolności korzystać. Znaczenie ciągłości dyskusji prawniczej wyrażało jeszcze w wieku XX przekonanie o wyjątkowości tego, co nazwano "prawniczym odkryciem”, czyli tego, co nowożytna nauka prawa wniosła nowego - na podobieństwo odkryć w naukach przyrodniczych czy wynalazków w naukach technicznych. Obok powściągliwości we wskazywaniu jako przykładów takich odkryć (np. konstrukcji culpa in contrahendo, rozróżnienia w przedstawicielstwie stosunku wewnętrznego i zewnętrznego ${ }^{1}$, spółki akcyjnej czy własności inte-

1 Zob. H. Dölle, Juristische Entdeckungen, Tübingen 1958, s. 3 i n.; Th. Hoeren (Hrsg.), Zivilrechtliche Entdecker, Muenchen 2001, s. 73 i n. lektualnej²) spotkamy i pogląd, że to, co przedstawia się jako odkrycia prawnicze, w ogóle na to miano nie zasługuje $^{3}$. Kilka lat temu Wolfgang Hoffmann-Riem stwierdził, iż fenomen określany jako odkrycie nazwiemy w dzisiejszej terminologii prawniczą innowacją ${ }^{4}$ Ten fenomen wyjaśnił jako „nowości w prawie”, których najwięcej wprowadza prawodawca ${ }^{5}$. O gwałtownych, kłopotliwych praktycznie zmianach w prawie wynikających z politycznej decyzji suwerena przypomina w tym numerze artykuł Agaty Pyrzyńskiej dotyczący wpływu brexitu na wybory do Parlamentu Europejskiego. Językowe utożsamienie przez W. Hoffmanna-Riema tego, co do niedawna uznawano za wyjątkowe i przełomowe, z codziennością prawodawcy przypomina to, co Niemcy nazywają Etikettenschwindel. Taką zmianę narracji można postrzegać jako przejaw odrzucania kluczowej wagi ciągłości w europejskiej dyskusji prawniczej. To prawda, że kontynuacja w nauce prawa nie ma tak klarownej i stabilnej postaci jak w matematyce. Wyidealizowanym, ale obrazowym ujęciem prawniczej kontynuacji jest wprowadzone przez Friedricha von Savigny’ego określenie „organiczny rozwój prawa" ${ }^{6}$. W ostatnich latach sformułowanie to ożyło wśród zarzutów wobec projektu szybkiej harmonizacji prawa prywatnego w Europie ${ }^{7}$. Za

2 F. Longchamps de Bérier, O prawniku w Rzeczypospolitej Nauk, „Zeszyty Naukowe Uniwersytetu Wrocławskiego” 1958, Sekcja A, nr 5, s. 9.

3 H. Honsell, Recht und Rechtswissenschaft in Österreich (w:) W. Berka, G. Magerl (Hrsg.), Wissenschaft in Österreich. Bilanzen und Perspektiven, Wien-Köln-Weimar 2006, s. 37.

4 W. Hoffmann-Riem, Innovation und Recht - Recht und Innovation, Recht in Ensemble seiner Kontexte, Tübingen 2016, s. 518.

5 Tamże, s. 527.

6 F.C. von Savigny, System des heutigen Römischen Rechts, Berlin 1840, s. 17.

7 H. Eidenmüller i in., Der Gemeinsame Referenzrahmen für das Europäische Privatrecht, ,JuristenZeitung” 2008, nr 11 (63), s. 530. 
formułą organicznego rozwoju stoi przekonanie, że naukowa refleksja nad wprowadzaniem nowości do prawa zakłada istnienie jakoś zobiektywizowanej prawniczej racjonalności. Ciągłość nauki prawa wyraża się w tym, że jednym z kryteriów racjonalności jest doświadczenie prawnicze. Jest ono przywoływane na różne sposoby pod szyldem historycznych wprowadzeń lub deklaracji o posiłkowaniu się metodą historyczną. Niekiedy elementy kontynuacji można dostrzec tylko poprzez sposób argumentacji. Takie formy trwania przeszłości w teraźniejszości dają pole i tym, którzy sięgają głębiej do dawnego prawa lub refleksji filozoficzno-prawnej, by włączyć się do dyskusji o tym, co ważne i aktualne w prawie dziś. Odwoływanie się do doświadczenia prawniczego nigdy nie oznaczało w naszej tradycji prostego kopiowania przeszłości. Odkrycia prawnicze w zakresie prawa prywatnego miały co prawda swoje inspiracje ${ }^{8}$ lub punkty odniesienia ${ }^{9}$ w spuściźnie wcześniejszej myśli prawniczej, ale oznaczały nową jakość. Mniej przełomowe modyfikacje czy hybrydy dawnych pojęć, instytucji lub reguł łatwiej poddawały się testowi racjonalności przy wykorzystaniu rozumowań prawniczych przekazywanych i doskonalonych w kolejnych pokoleniach. Odrzucenie tak rozumianej kontynuacji może przyspieszyć drogę ku nowościom w prawie dokonywanym głównie przez prawodawcę realizującego swoje cele polityczne. Krótszą drogę do budowania nowego świata wytyczyłoby jedynie zabicie wszystkich prawników, co proponował Dick rzeźnik w dramacie Szekspira „Henryk VI”10. Dlatego uważam, że nazwanie innowacją każdej nowości w prawie lub dyskusji o prawie jest mylące. Ogólne zastrzeżenie, że innowacje mogą powodować

8 Np. co do culpa in contrahendo: R. von Jhering, Culpa in contrahendo der Schadenersatz bei nichtigen oder nicht zur Perfektion gelangten Verträgen, „Jahrbuch für die Dogmatik des heutigen römischen und deutschen Privatrechts" 1861, $\mathrm{nr} 4$, s. 64 i n.; co do wpływu nadzwyczajnej zmiany okoliczności na zobowiązanie: Uzasadnienie projektu kodeksu zobowiązań z uwzględnieniem ostatecznego tekstu kodeksu w opracowaniu głównego referenta projektu Prof. Romana Longchamps de Berier. Art. 239-293, Warszawa 1936, s. 421.

9 Np. co do praw na dobrach niematerialnych: J.L. Neustetel, Der Büchernachdruck, nach Römischen Recht betrachtet, Heidelberg 1824.

10 W. Szekspir, Król Henryk VI, cz. 2, akt IV, scena 2. pozytywne lub negatywne skutki ${ }^{11}$, z błędu nie wyprowadza. Raczej wzmacnia przekonanie, że poprzez prawo można próbować wszystkiego. Określenie nowości jako innowacji prawniczej powinno być wynikiem wartościowania. Nie chodzi tu oczywiście o jednomyślność, bo kontrowersje są trwale i naturalnie wpisane w prawniczą debatę. Rzecz w tym, że racjonalność i użyteczność tez formułowanych w ramach wolnej naukowej dyskusji o prawie domagają się jakiejś obiektywizacji. Kontynuacja rozwoju w formule właściwej tradycji prawnej może temu sprzyjać. W ten sposób konkretyzuje się postawione na wstępie pytanie: jak pogodzić dyskusję o tym, co aktualne, $\mathrm{z}$ akcentowaniem wagi tradycji prawnej? Spójrzmy pod tym kątem na najnowszy numer „Forum Prawniczego”. Jednym z pól, na którym dyskutuje się potrzebę innowacji w prawie, są możliwości wynikające z rozwoju technologii informatycznych. W tym zeszycie aż trzy artykuły dotykają tej kwestii. Rozważania Pawła Księżaka i Sylwii Wojtczak nawiązują do rodzącego się problemu odpowiedzialności za szkody wyrządzone przez maszyny „inteligentne”. Autorzy pokazali, jak mało użyteczne dla dyskusji prawniczej jest przyjęcie za punkt wyjścia - dla oczekiwanych zmian w prawie wziętych z literatury science fiction praw Asimova. W uzupełnieniu tych ciekawych rozważań warto odnotować, jak odmienne od komentowanej rezolucji Parlamentu Europejskiego ramy dla poszukiwania prawniczej innowacji daje eksperckie opracowanie Expert Group on Liability and New Technologies z roku $2019^{12}$. Istota tej odmienności tkwi w tym, że na to opracowanie składa się szkic kluczowych problemów przyjmowania i wytyczania granic odpowiedzialności obiektywnej - zbudowany przy użyciu metody porównawczej i elementów metody historycznej. Wobec zupełnie nowych wyzwań może wyjść poza granice ciekawostki wspomnienie o inspiracjach dla zasad odpowiedzialności za kierowane sztuczną inteligencją roboty

11 Zob. W. Hofmann-Reim, Innovation..., s. 521.

12 Expert Group on Liability and New Technologies - New Technologies Formation, Liability for Artificial Intelligence and Other Emerging Digital Technologies, European Union, 2019, https://ec.europa.eu/transparency/regexpert/index. $\mathrm{cfm} ? \mathrm{do}=$ groupDetail.groupMeetingDoc\&docid $=36608$ (dostęp 27.05.2020). 
dostrzeganych w anachronicznym - wydawałoby się rozwiązaniu noksalnej odpowiedzialności właściciela za szkody wyrządzone przez jego niewolnika ${ }^{13}$. To chyba jedyny oparty na realnym doświadczeniu punkt wyjścia dla krytycznej refleksji nad modelami alokacji ryzyka odpowiedzialności za szkodę wyrządzoną przez inteligentnego sprawcę, który nie jest podmiotem prawa. Znacznie bliższe dzisiejszej codzienności, doniosłe praktycznie są rozważania poświęcone możliwości dokonywania czynności notarialnych online (Ewy Rott-Pietrzyk, Fryderyka Zolla, Dariusza Szostka i Mateusza Grochowskiego). Są one dobrym przykładem, że nie należy utożsamiać kontynuacji w prawniczej dyskusji z rutyną prawniczej praktyki. Autorzy formułują tezę, iż już w obecnym stanie prawnym możliwe jest przełamanie w pewnym zakresie konserwatywnej postawy notariuszy poprzez przyjęcie interpretacji dopuszczającej dokonywanie czynności notarialnych online. Obok argumentów dogmatycznych pojawia się i ten, że gwałtowne zmiany historyczne niejednokrotnie powodowały w prawie prywatnym innowacyjne podejście do istniejących konstrukcji prawnych. To prawda. Co więcej, historia pozwala wskazać przykłady reinterpretacji prawa, gdy służyło to ochronie znanych $\mathrm{z}$ doświadczenia prawniczego wartości ${ }^{14}$. Jako przykład tak zakorzenionego myślenia postrzegam zalecenie autorów, by przeprowadzić pogłębioną refleksję nad zakresem podmiotowym stosowania czynności notarialnych online, aby nie naruszyć funkcji ochronnej wymogu osobistej obecności. Reinterpretacja prawa może znaleźć wsparcie także w prawniczym doświadczeniu. Natomiast reinterpretacja prawa niezakorzeniona $\mathrm{w}$ znanych $\mathrm{z}$ doświadczenia prawniczego wartościach potrzebuje raczej inspiracji w zmianach ustawowych lub będzie wynikała z daleko idącego upolitycznienia procesu stosowania prawa ${ }^{15}$. Zamykający numer artykuł recenzyjny Jana Rudni-

13 Tamże, s. 25, przyp. 63.

14 Np. wyrok francuskiego Sądu Kasacyjnego z dnia 15 czerwca 1892 r. w sprawie Julien Patureau c/ Boudier (DP 92. 1. 596, S. 93. 1. 281, note Labbé).

15 Por. P. Łącki, Zmiana znaczenia pojęcia małżeństwa $w$ niemieckiej ustawie zasadniczej. O meandrach dynamicznej wykładni postanowień konstytucyjnych, „Forum Prawnicze” 2018, nr 2 (46), s. 33 i n. ckiego jest z kolei ciekawym przykładem, że występujące pod szyldem nowoczesności uproszczone odrzucenie doświadczenia prawniczego może nieść ze sobą deficyty argumentacyjne. W recenzowanej książce przekonująca teza o użyteczności wideotestamentu została powiązana z postulatem odejścia od „rzymskiego wzorca testamentu”. Trudno nie zgodzić się z recenzentem, że z perspektywy nowożytności i współczesności ten wzorzec to przede wszystkim wartości, których konkretyzowanie i ważenie pozwala opisać rozwój prawa testamentowego w Europie. W historii proponowanych przez wieki form testamentu możemy dostrzec wspólne osie. Wśród nich jest troska o zapewnienie stanowczości i samodzielności oświadczenia spadkodawcy. Takie spojrzenie na doświadczenie prawa prywatnego powinno - jak zauważył recenzent wzbogacić argumentację, skłonić do ostrożności przed bezkrytycznym uznaniem stanowczości animus testandi $\mathrm{w}$ wideotestamencie, skoro cyfrowe nagrania powstają łatwo i masowo.

Artykuł Michała Królikowskiego można odczytać jako propozycję drogi ku innowacji w rozumowaniach karnistycznych poprzez refleksję nad doniosłością wartości zobiektywizowanych w kulturze prawnej i etycznych intuicjach społeczeństwa. W europejskiej tradycji prawnej nietrudno znaleźć przykłady słabości dwóch zakwestionowanych przez M. Królikowskiego rozumowań: izolowania argumentacji prawniczej od wartościowania oraz przesadnej wiary w efektywność systemowego myślenia o prawie. Czy jednak naprawdę da się oderwać wartościowanie od dyskusji prawniczej? Z pewnością można je ukryć. Metody porządkują prawnicze rozumowania służące formułowaniu lub interpretowaniu tekstu. Jednak wbrew nadziejom Rudolfa von Jheringa nie udało się sprowadzić naukowości prawoznawstwa do dyskusji o metodzie prawniczej w kategoriach prawdziwości. Pluralizm i elastyczność metod prawniczych są faktem. Plastycznie i konkretnie służy refleksji o prawniczych innowacjach artykuł Franciszka Longchamps de Bérier otwierający numer. Ważnym składnikiem odpowiedzi na pytanie „Co pozostaje po uczonym prawniku?” jest przypomnienie myśli o prawie wypowiedzianych ponad pół wieku temu przez dziadka autora, profesora prawa administracyjnego o tym samym imieniu i nazwisku. Skłania do zastanowienia, że ów uczony - 
chwalony dziś za to, że przyczynił się do „utrzymania więzi polskiego prawa administracyjnego”, oraz że „wskazał następnym pokoleniom (...) realistyczne wartościowanie połączone z troską o człowieka i własne państwo" - na pytanie o istotę prawa przyznawał, iż wszyscy przytaczamy antyczną definicję prawa Celsusa ius est ars boni et aequi, czyli „prawo jest sztuką tego, co dobre i sprawiedliwe".

Kwalifikowanie tylko niektórych nowości jako prawniczych innowacji można zatem rozumieć jako konsekwencję tego, że prawo jest swoistą sztuką (ars). Innowacją prawniczą będzie to, co odpowiada realistycznie na konkretną potrzebę, ale uwzględnienia wartości zobiektywizowane dzięki ciągłości prawniczej dyskusji. Ta kontynuacja tworzy tradycję prawną. Świadomość uchwyconych na tej drodze wartości i potrzeby ich ważenia staje się osią tradycji. Oczywiście, to ważenie konkurujących wartości - przypisywanie im różnej wagi - może dać odmienne propozycje ad casum. Dlatego kontrowersje są trwałym elementem nauki i praktyki prawa. Co więcej, doświadczenie i w tym punkcie zaleca realizm i krytycyzm, bo najwyższe prawo może stać się instrumentem bezprawia ${ }^{16}$ - słów można nadużywać, natomiast wiarygodne są rzeczywiste zachowania ${ }^{17}$. Powstające poprzez takie wartościowania innowacje prawnicze będą czymś innym niż spory polityczne czy oryginalność sama przez się. Uznanie i nieprzekraczanie tych granic wytyczy - w co wierzę - pole dobrego korzystania z wolności prawniczej dyskusji. Mieszczące się w tym polu publikacje będą użytecznym wsparciem dla bieżącej praktyki i dydaktyki prawa. W pewnym zakresie mogą stać się innowacjami prawniczymi. Dziesiąta rocznica „Forum Prawniczego" niech będzie okazją, by życzyć pismu publikacji niosących innowacje. Do tego dochodzi życzenie, by rosnąca liczba jego cytowań łączyła się z inspiracyjnym oddziaływaniem na uczenie, stosowanie i tworzenie prawa. Oczywiście, podobnie jak w losach spuścizny po uczonym prawniku - także przy prowadzeniu czasopisma prawniczego potrzeba trochę szczęścia.

\section{Wojciech Dajczak}

16 Summum ius summa iniuria (Cic. off. 1,33).

17 Verba volant, exempla trahunt (maksyma inspirowana Sen. epist. 6,5). 